\title{
KECERDASAN EMOSI DAN DUKUNGAN KELUARGA DENGAN PENERIMAAN DIRI ORANG TUA YANG MEMILIKI ANAK BERKEBUTUHAN KHUSUS (ABK)
}

\author{
Yiyi Dwi Panti Rahayu, Latifah Nur Ahyani \\ Fakultas Psikologi, Universitas Muria Kudus \\ ydwi.rahayu@yahoo.co.id
}

\begin{abstract}
Abstrak
Penerimaan diri merupakan kemampuan menerima segala hal yang ada pada diri sendiri baik kekurangan maupun kelebihan yang dimiliki, sehingga bila terjadi peristiwa yang kurang menyenangkan maka individu akan mampu berfikir logis tentang baik buruknya masalah yang terjadi tanpa menimbulkan perasaan, permusuhan, perasaan rendah diri, malu, dan rasa tidak aman. Banyak faktor yang dapat mempengaruhi penerimaan diri diantaranya kecerdasan emosi dan dukungan keluarga. Tujuan penelitian ini untuk mengetahui ada tidaknya hubungan antara penerimaan diri sebagai variabel tergantung, serta kecerdasan emosi dan dukungan keluarga sebagai variabel bebas. Metode penelitian yang digunakan dalam penelitian ini adalah metode kuantitatif, dengan teknik incidental sampling yaitu penentuan sampel secara kebetulan kepada 40 orang tua yang memiliki anak berkebutuhan khusus. Analisis data penelitian ini menggunakan teknik analisis Regresi Dua Prediktor, dan pengolahan data Statistical Packages for Social Sciences 16.0 for window. Berdasarkan hasil analisis data yang telah dilakukan didapatkan hasil penelitian bahwa ada hubungan positif yang sangat signifikan antara kecerdasan emosional dengan penerimaan diri dan ada hubungan positif yang sangat signifikan antara dukungan keluarga dengan penerimaan diri. Sumbangan efektif kecerdasan emosi dan dukungan keluarga terhadap penerimaan diri sebesar $58,7 \%$. Sedangkan sumbangan efektif yang diberikan variabel kecerdasan emosi terhadap penerimaan diri sebesar $55,5 \%$, untuk variabel dukungan keluarga terhadap penerimaan diri mempunyai sumbangan efektif sebesar $21,3 \%$.

Kata Kunci: Penerimaan Diri, Kecerdasan Emosi, Dukungan Keluaga
\end{abstract}

\begin{abstract}
Self-acceptance is the ability to accept everything that is in it self both shortcomings and advantages, so that when events occur less favorable then the individual will be able to think logically about the merits of the problems that occur without cause feelings, hostility, feelings of inferiority, shame and insecurity. Many factors can affect the acceptance of which emotional intelligence and family support. The purpose of this study to know whether there is a relationship between self-acceptance as dependent variables, as well as emotional intelligence and family support as independent variables. The method used in this research is quantitative method with incidental sampling technique is the determination of the sample by chance to the 40 parents who have special needs children. This study data analysis using regression analysis techniques two predictors, and data processing using the program Statistical Packages for Social Sciences 16.0 for windows. Based on the results of data analysis that has been done, the results obtained research that there is a very significant positive relationship between emotional intelligence with self-acceptance and there is a very significant positive relationship between family support with self-acceptance. Effective contribution of emotional intelligence and family support to self-acceptance of $58.7 \%$. While the effective contribution given emotional intelligence variable to self-acceptance of $55.5 \%$, for family support variables on selfacceptance has an effective contribution of $21.3 \%$.
\end{abstract}

Keywords: Self Acceptance, Emotional Intelligence, Family Support

(C) 2017 Universitas Muria Kudus 


\section{PENDAHULUAN}

Kelahiran seorang anak dalam sebuah keluarga adalah suatu bagian yang indah, bahkan anak dikatakan sebagai salah satu faktor yang mempengaruhi stabilitas pernikahan (Hurlock, 2013). Menurut Rachmayanti \& Zulkaida (2007), setiap orang tua akan mengharapkan bayinya terlahir sehat dan normal, tidak terdapat cacat fisik, mental, ataupun keduanya. Akan tetapi Feldman (Somantri, 2007) menyatakan bahwa pada kenyataannya perkembangan setiap anak itu berbeda-beda, dimana perkembangan fisik anak normal kemungkinan dapat menyesuaikan pada situasi yang ada, sedangkan perkembangan anak yang menyimpang akan menghambat penyesuaian anak tersebut di lingkungannya.

Anak berkebutuhan khusus adalah anak dengan karakteristik khusus yang berbeda dengan anak pada umumnya tanpa selalu menunjukkan pada ketidakmampuan mental, emosi atau fisik (Geniofam, 2010). Data dari Tim Nasional Percepatan Penanggulangan Kemiskinan (TNP2K), hingga 2011 jumlah anak dengan berkebutuhan khusus di Indonesia mencapai 18 ribu anak. Demikian sebagian besar dari mereka yang tidak mendapatkan hak sesuai dengan kapasitasnya, anak dikurung di dalam rumah karena orang tua merasa malu dengan lingkungan sekitarnya terkait kondisi putra atau putrinya. Di sejumlah desa masih ditemukan kasus anak dirantai atau dipasung atau hanya sekedar mengantar anak ke tempat terapi saja tetapi tidak peduli seperti apa perkembangannya. Ada juga yang diserahkan perawatannya kepada babysitter atau pembantu untuk merawat anaknya. Fakta lainnya, pelayanan kesehatan, pendidikan, serta fasilitas umum bagi anak-anak berkebutuhan khusus di Indonesia memang masih minim. Tenaga pengajar pun belum banyak yang mumpuni mendampingi anak-anak berkebutuhan khusus, masyarakat juga kerap mem-bully anak berkebutuhan khusus dan banyak sekolah menolak keberadaan anak berkebutuhan khusus (Zulqaidah, 2016).

Pendapat Aydin \& Yamac (2014) dijelaskan bahwa kegagalan untuk memenuhi harapan memiliki bayi yang sehat dan impian masa depan terkait juga mungkin memiliki dampak yang signifikan terhadap perilaku penerimaan-penolakan orang tua dengan anak disabiltas. Menurut Onder dan Gulay (Aydin \& Yamac, 2014), tingkat penolakan yang lebih tinggi ditentukan antara orang tua dengan anak cacat mental dibandingkan dengan orang tua dari anak-anak yang pengembangan normal.

Obi, Cantwell-Barti, dan Kaur (Fareo, 2015) mengatakan bahwa kelahiran seorang anak dengan kecacatan dalam sebuah keluarga dikatakan menjadi kejutan bagi orang tua dan keluarga, dan menimbulkan banyak tantangan bagi mereka. Keluarganya akan mengalami trauma, kesedihan, rasa bersalah, agresi, penolakan, stres, dan ketegangan, dan bahkan kecenderungan terhadap pembunuhan dan bunuh diri. Menurut Fareo (2015), memiliki anak-anak dengan kebutuhan khusus yang parah akan menguras sejumlah waktu, tenaga, dan uang yang sangat besar. 
Menurut Somantri (2007), reaksi orang tua terhadap anak kebutuhan yang berkebutuhan khusus biasanya akan menerima secara realistik dimana orang tua akan menyangkal bahwa anaknya tidak termasuk anak berkebutuhan khusus (tidak percaya), sehingga menimbulkan perlindungan yang berlebihan, penolakan secara tertutup yaitu mengasingkan anaknya, menolak secara terbuka yaitu bersikap masa bodoh dan tidak peduli dengan kebutuhan anak tersebut.

Somantri (2007) menyatakan lingkungan keluarga adalah lingkungan sosial pertama bagi anak sehingga memberikan pengaruh besar bagi perkembangan anaknya. Sikap orang tua yang baik untuk perkembangan anaknya adalah sikap mengerti, mencintai, dan menaruh perhatian pada anak. Orang tua yang kurang hangat atau menolak anak akan sangat berpengaruh pada perkembangan anak.

Allport (Schult, 1991) mengatakan bahwa peranan orang tua sangat penting apabila anak yang menerima keamanan dan kasih sayang yang cukup maka pertumbuhan psikologis positif. Ketika seorang anak kurang kasih sayang dan tidak aman maka anak akan menjadi tidak nyaman, agresif, suka menuntut, dan pertumbuhan psikologisnya berkurang. Menurut Schult (1991), penerimaan diri adalah mampu menerima segi yang ada pada diri termasuk kelemahan ataupun kekurangan tanpa menyerah pada kenyataan yang ada.

Menurut Hurlock (2013), sikap positif orang tua terhadap anak berkebutuhan khusus akan membantu anak mampu memandang dirinya secara realistis serta menilai kekuatan dan kelemahannya secara objektif. Hutt dan Gibby (Eliyanto dan Hendriani, 2013) mengatakan bahwa orang tua yang menerima keadaan anaknya adalah orang tua yang mengakui dan menerima kenyataan akan ketidakmampuan atau kekurangan anak.

Menurut Rogers (Pancawati, 2013), penerimaan merupakan sikap seseorang yang menerima orang lain apa adanya secara keseluruhan, tanpa disertai persyaratan ataupun penilaian. Sobur (2003) mengatakan bahwa "mereka yang lebih ikhlas menerima kenyataan diri akan lebih cepat menyerap sesuatu daripada mereka yang kurang ikhlas menerima realitas dirinya".

Penerimaan diri sangatlah penting untuk kesehatan mental serta sebagai karakteristik aktualisasi diri dan ketenangan. Menurut Anderson (Sugiarti, 2008), penerimaan diri sangat berpengaruh bagaimana seseorang menjalani hidup. Seseorang yang mampu menerima dirinya, maka ia tidak akan takut memandang dirinya secara jujur, baik di dalam (hati/pikiran/perasaan) maupun di luar (perilaku, penampilan).

Penelitian yang dilakukan oleh Levianti (2013) menunjukkan bahwa ketiga subjek memiliki penerimaan yang baik dikarenakan subjek ketiga beralasan ingin menjadi ibu yang baik dan membantu anaknya untuk dapat menjadi seseorang yang tidak putus asa dan mandiri. Subjek ketiga mengakui bahwa ia masih sering sedih bila melihat anak-anak lain namun subjek tidak mau berlama-lama larut dalam perasaan seperti itu, mencoba untuk 
berfikir hal-hal yang positif agar terus dapat memberikan yang terbaik bagi anaknya. Subjek kedua juga memiliki penerimaan diri yang baik dimana memiliki harapan agar anaknya kelak dapat menguasai berbagai macam bahasa, membuatnya tetap semangat untuk mengajarkan anaknya berbagai bahasa. Terlebih lagi setiap ia mulai mengajar anak-nya bahasa, anaknya dapat dengan cepat mempelajarinya dan mempraktekkannya. Subjek pertama juga merasa nyaman menjalani hari-harinya bersama anaknya, tanggung jawabnya sebagai ibu ia jalankan dengan sebaik-baiknya.

Dampak positif dari penerimaan diri adalah orang tua mengakui dan menerima keterbatasan anak seperti halnya yang di jelaskan oleh Hutt dan Gibby (Eliyanto dan Hendriani, 2013) mengatakan bahwa orang tua yang menerima keadaan anaknya adalah orang tua yang mengakui dan menerima kenyataan akan ketidakmampuan atau kekurangan anak. Sedangkan dampak dari penerimaan negatif yaitu orang tua akan menyangkal kehadiran anaknya, masa bodoh, kecewa, malu ataupun melakukan penolakan. Menurut Somantri (2007), menyatakan bahwa orang tua akan menyangkal bahwa anaknya tidak termasuk anak berkebutuhan khusus (tidak percaya), penolakan secara tertutup yaitu mengasingkan anaknya, menolak secara terbuka yaitu bersikap masa bodoh dan tidak peduli dengan kebutuhan anak tersebut.

Hal tersebut didukung oleh penelitian yang dilakukan Faradina (2016), hasil penelitian menunjukkan bahwa pada ketiga subjek yang ditelitinya memiliki penerimaan diiri yang berbeda dalam menerima anak berkebutuhan khusus. Dua subjek memiliki penerimaan diri yang positif karena subjek pertama pasrah dengan keadaan anaknya namun berusaha untuk memahami kondisi dan tidak malu dengan kekurangan anaknya, subjek kedua dapat berusaha untuk ikhlas dan memahami keadaan anaknya serta selalu mendukung segala kegiatan anak termasuk dalam hal sekolah. Subjek ketiga memiliki penerimaan diri yang negatif karena subjek merasa kondisi anaknya tidaklah sesuai dengan harapannya dan subjek selalu merasa malu dan takut ketika orang lain mengetahui kondisi anaknya.

Menurut Hurlock (Prayitna, Lestari, dan Supriyono, 2014) faktor-faktor yang mempengaruhi penerimaan diri yaitu pemahaman diri, harapan yang realistis, tidak adanya hambatan-hambatan dari lingkungan, tingkah laku sosial yang mendukung (dukungan sosial), tidak adanya tekanan emosi yang berat, pengaruh keberhasilan yang dialami, baik secara kualitatif maupun kuantitatif, identifikasi dengan orang yang mempunyai penyesuaian diri yang baik, cara seseorang melihat diri sendiri (konsep diri), pendidikan yang baik pada masa kanakkanak.

Hurlock (2013) menjelaskan bahwa tidak adanya tekanan emosi membuat seseorang dapat melakukan yang terbaik dan dapat berpandangan keluar dan tidak memiliki pandangan hanya ke dalam diri saja. Tanpa tekanan emosi juga dapat membuat seseorang santai dan bahagia. Kondisi-kondisi ini memberikan sumbangan positif bagi penilaian terhadap 
lingkungan sosial yang menjadi dasar terhadap penilaian diri sendiri dan terhadap penerimaan diri. Disamping itu, Salovey dan Mayer (Goleman, 2000) berpendapat bahwa orang yang cerdas secara emosi lebih mampu mengenali perasaan dan sadar akan suasana hati maupun pikiran tentang suasana hatinya sendiri. Dengan demikian, individu tidak mudah larut dan dikuasai emosinya. Individu juga mampu mengendalikan kestabilan emosinya, bebas dari perasaan cemas, kemurungan, ketersinggungan akibat adanya tekanan emosi berat yang muncul dari luar dirinya maupun diri sendiri. Sehingga sangatlah penting individu memiliki kecerdasan emosi, karena dengan kecerdasan emosi, individu dapat menerima dirinya sendiri.

Hasil penelitian Mirza (2016) menunjukkan adanya hubungan antara kecerdasan emosional dengan penerimaan diri pada santri Pondok Pesantren Al-Islam Genengan Mojokerto Maknanya, semakin tinggi tingkat kecerdasan emosional maka semakin tinggi pula tingkat penerimaan diri santri. Sebaliknya, semakin rendah tingkat kecerdasan emosional, maka semakin rendah pula tingkat penerimaan diri santri.

Menurut Salovey, Mayer, Caruso \& Lopes, Brackett, Mayer \& Warner (2004), penerimaan diri dapat dipengaruhi oleh kecerdasan emosi. Salovey dan Mayer (Goleman, 2000) berpendapat bahwa orang yang cerdas emosinya lebih mampu mengenali perasaan dan sadar akan suasana hati maupun pikiran tentang suasana hatinya sendiri. Dengan demikian, individu tidak mudah larut dan dikuasai emosinya. Individu juga mampu mengendalikan kestabilan emosinya, bebas dari perasaan cemas, kemurungan, ketersinggungan akibat adanya tekanan emosi berat yang muncul dari luar dirinya maupun diri sendiri.

Goleman (2000), berpendapat bahwa kecerdasan emosional merupakan pengendalian diri, semangat dan ketekunan, serta mampu untuk memotivasi diri sendiri dan bertahan menghadapi frustasi, kesanggupan untuk mengendalikan dorongan hati dan emosi, tidak melebih-lebihkan kesenangan, mengatur suasana hati dan menjaga agar beban stres tidak melumpuhkan kemampuan berpikir, untuk membaca perasaan terdalam orang lain (empati) dan berdoa, untuk memelihara hubungan dengan sebaik-baiknya, kemampuan untuk menyelesaikan konflik.

Landa, Martos \& Zafra (2010) berpendapat jika seorang ibu memiliki kecerdasan emosi yang tinggi, maka seorang ibu memiliki penerimaan diri yang tinggi. Darling (Eliyanto dan Hendriani, 2013) menyatakan dengan memiliki kecerdasan emosi yang tinggi akan mempengaruhi tingkat penerimaan diri ibu terhadap anak kandungnya. Hal ini sejalan dengan penelitian yang dilakukan oleh Eliyanto dan Hendriani (2013), menunjukkan adanya hubungan antara kecerdasan emosi dengan penerimaan diri ibu anak kandung yang mengalami cerebral palsy. Semakin tinggi kecerdasan emosi ibu anak kandung yang mengalami cerebral palsy akan semakin tinggi penerimaan diri anak kandung yang 
mengalami cerebral palsy, sebaliknya semakin rendah kecerdasan emosi anak kandung yang mengalami cerebral palsy maka semakin rendah penerimaan diri ibu anak kandung yang mengalami cerebral palsy.

Penelitian yang dilakukan oleh Levianti (2013) dimana dari ketiga subjek yang diteliti memiliki kesamaan pada penarikan diri terhadap lingkungan. Perasaan malu dan ketakutan akan dipandang rendah oleh keluarga besar lebih memilih tertutup kepada orang lain. Hal tersebut terjadi karena kurangnya dukungan dari keluarga besar. Dalam hal ini tentunya dukungan keluarga sangat penting dimana dukungan yang baik akan membuat individu tidak terlalu lama tenggelam dalam perasaan dukanya, serta dapat membantu individu untuk kembali berfikir realistik. Hurlock (2013) menyatakan bahwa sikap-sikap anggota keluarga yang menyenangkan dan tidak adanya prasangka buruk lingkungan terhadap seorang ibu yang mengalami kondisi sulit untuk menerima dirinya sendiri, merupakan salah satu faktor seseorang dapat melakukan penerimaan diri.

Menurut Sarasvati (2004), penerimaan orang tua terhadap anak dipengaruhi oleh ada atau tidaknya dukungan sosial dari orang-orang disekitar karena manusia takkan lepas dari orang lain. Menurut Sarafino (1990), dukungan sosial sendiri dapat berasal dari berbagai sumber yaitu pasangan hidup, keluarga, pacar, teman, rekan kerja, dan organisasi komunitas. Dukungan sosial yang bersumber dari keluarga disebut dukungan sosial keluarga.

Friedman (1998) menjelaskan bahwa dukungan keluarga adalah sikap, tindakan serta penerimaan keluarga terhadap anggotanya. Anggota keluarga dipandang sebagai bagian yang tidak terpusahkan dalam lingkungan keluarga. Anggota keluarga memandang bahwa orang yang bersifat mendukung selalu siap memberikan pertolongan dan bantuan ketika diperlukan. Brooks (2011) berpendapat bahwa dukungan keluarga berasal dari dukungan kerabat, kakek, nenek, dan atau berasal dari anggota keluarga lain.

Penelitian yang dilakukan oleh Twistiandayani dan Handika (2015), menunjukkan hasil bahwa ada hubungan antara dukungan keluarga dengan penerimaan diri ibu pada anak autis. Semakin tinggi dukungan keluarga terhadap ibu yang memiliki anak autis akan semakin tinggi penerimaan diri ibu pada anak autis, sebaliknya semakin rendah dukungan keluarga terhadap ibu yang memiliki anak autis maka semakin rendah penerimaan diri ibu pada anak autis.

Berdasarkan permasalahan itulah peneliti ingin meneliti tentang kecerdasan emosi dan dukungan keluarga dengan penerimaan diri orang tua yang memiliki anak berkebutuhan khusus (ABK). Tujuan penelitian ini untuk mengetahui ada tidaknya hubungan antara penerimaan diri sebagai variabel tergantung, serta kecerdasan emosi dan dukungan keluarga sebagai variabel bebas. 


\section{KAJ IAN TE ORITIS}

\section{Penerimaan Diri}

Hurlock (2013) mengemukakan bahwa penerimaan diri merupakan kemampuan menerima segala hal yang ada pada diri sendiri baik kekurangan maupun kelebihan yang dimiliki, sehingga bila terjadi peristiwa yang kurang menyenangkan maka individu akan mampu berfikir logis tentang baik buruknya masalah yang terjadi tanpa menimbulkan perasaan, permusuhan, perasaan rendah diri, malu, dan rasa tidak aman

Ananwong, Tuicomepee, Kotrajaras (2013) menjelaskan bahwa "penerimaan diri adalah kesadaran diri dari diri individu melalui proses memahami kehidupan sendiri dengan kenyataan yang wajar, memahami pro dan kontra, dan menerima keterbatasan dan menilai kesalahan sendiri”.

Faktor-faktor yang Mempengaruhi Penerimaan Diri

Menurut Hurlock (2013), faktor-faktor yang mempengaruhi penerimaan diri adalah: pemahaman diri, harapan yang realistis, tidak adanya hambatan-hambatan dari lingkungan, tingkah laku sosial yang mendukung (dukungan sosial), tidak adanya tekanan emosi yang berat, pengaruh keberhasilan yang dialami, baik secara kualitatif maupun kuantitatif, identifikasi dengan orang yang mempunyai penyesuaian diri yang baik, cara seseorang melihat diri sendiri (konsep diri), pendidikan yang baik pada masa kanak-kanak.

Hurlock (2013) menjelaskan bahwa tidak adanya tekanan emosi membuat seseorang dapat melakukan yang terbaik dan dapat berpandangan keluar dan tidak memiliki pandangan hanya ke dalam diri saja. Tanpa tekanan emosi juga dapat membuat seseorang santai dan bahagia. Kondisi-kondisi ini memberikan sumbangan positif bagi penilaian terhadap lingkungan sosial yang menjadi dasar terhadap penilaian diri sendiri dan terhadap penerimaan diri.

Disamping itu, Salovey dan Mayer (Goleman, 2000) berpendapat bahwa orang yang cerdas secara emosi lebih mampu mengenali perasaan dan sadar akan suasana hati maupun pikiran tentang suasana hatinya sendiri. Dengan demikian, individu tidak mudah larut dan dikuasai emosinya. Individu juga mampu mengendalikan kestabilan emosinya, bebas dari perasaan cemas, kemurungan, ketersinggungan akibat adanya tekanan emosi berat yang muncul dari luar dirinya maupun diri sendiri.

Menurut Salovey, Mayer, Caruso \& Lopes, Brackett, Mayer \& Warner (2004), penerimaan diri dapat dipengaruhi oleh kecerdasan emosi. Salovey dan Mayer (Goleman, 2000) berpendapat bahwa orang yang cerdas secara emosi lebih mampu mengenali perasaan dan sadar akan suasana hati maupun pikiran tentang suasana hatinya sendiri. Dengan demikian, individu tidak mudah larut dan dikuasai emosinya. Individu juga mampu mengendalikan kestabilan emosinya, bebas dari perasaan cemas, kemurungan, 
ketersinggungan akibat adanya tekanan emosi berat yang muncul dari luar dirinya maupun diri sendiri.

Menurut Hurlock (2013), tingkah laku sosial yang mendukung adalah peranan lingkungan sosial terhadap seseorang dapat membentuk tingkah laku orang. Seseorang yang mengalami perlakuan lingkungan sosial yang mendukung akan dapat menerima dirinya dengan lebih baik. Sedangkan Sarasvati (2004), penerimaan orang tua terhadap anak dipengaruhi oleh ada atau tidaknya dukungan sosial dari orang-orang disekitar karena manusia takkan lepas dari orang lain. Menurut Sarafino (1990), dukungan sosial dapat berasal dari berbagai sumber yaitu pasangan hidup, keluarga, pacar, teman, rekan kerja, dan organisasi komunitas. Dukungan sosial yang bersumber dari keluarga disebut dukungan sosial keluarga.

Karakteristik Penerimaan Diri

Menurut Jersild, Brook \& Brook (1978), karakteristik penerimaan diri yaitu:memiliki penilaian realistis terhadap potensi yang dimiliki serta menghargai dirinya sendiri, memiliki keyakinan akan prinsip tanpa terpaku atas pendapat orang lain, menyadari kekurangannya tanpa menyalahkan diri sendiri, memiliki kemampuan untuk memandang dirinya secara realistis tanpa harus menyalahkan dirinya sendiri terhadap keadaan-keadaan di luar kendali diri sendiri, memiliki spontanitas dan tanggung jawab untuk dirinya sendiri

\section{Kecerdasan Emosional}

Menurut Goleman (2015), kecerdasan emosi adalah kemampuan untuk memotivasi diri sendiri, bertahan untuk menghadapi frustasi, mengendalikan dorongan hati dan tidak melebih-lebihkan kesenangan, mengatur suasana hati dan menjaga agar beban stres tidak melumpuhkan kemampuan berpikir, berempati serta berdo'a.

Mayer dan Salovey (Batool, 2013) menjelaskan "kecerdasan emosional melibatkan kemampuan untuk memahami secara akurat, menilai, dan mengekspresikan emosi; kemampuan untuk mengakses dan/atau menghasilkan perasaan ketika memfasilitasi pola pikir; kemampuan untuk memahami emosi dan pengetahuan emosional; dan kemampuan untuk mengatur emosi untuk mempromosikan pertumbuhan emosi dan intelektual".

\section{Aspek-aspek Kecerdasan Emosional}

Menurut Goleman (2015), aspek-aspek kecerdasan emosional: mengenali emosi diri, mengelola emosi, memotivasi diri sendiri, mengenali emosi orang lain atau kemampuan ini bisa disebut empati, membina hubungan. 


\section{Dukungan Keluarga}

Friedman (1998) menjelaskan bahwa dukungan keluarga adalah sikap, tindakan serta penerimaan keluarga terhadap anggotanya. Anggota keluarga dipandang sebagai bagian yang tidak terpusahkan dalam lingkungan keluarga. Anggota keluarga memandang bahwa orang yang bersifat mendukung selalu siap memberikan pertolongan dan bantuan ketika diperlukan.

Taylor, Peplau, dan Sears (2009) berpendapat dukungan keluarga merupakan bantuan yang dapat diberikan kepada keluarga lain berupa barang, jasa, informasi dan nasehat, yang mana membuat penerima dukungan akan merasa disayang, dihargai, dan tentram. Friedman (1998), dukungan sosial keluarga dapat berupa dukungan sosial keluarga internal, seperti dukungan dari suami dan istri serta dukungan dari saudara kandung atau dukungan keluarga eksternal seperti dukungan dari saudara, teman, tetangga. Brooks (2011) berpendapat bahwa dukungan keluarga berasal dari dukungan kerabat, kakek, nenek, dan atau berasal dari anggota keluarga lain.

\section{Aspek-aspek Dukungan Keluarga}

Menurut Friedman (1998), ada empat aspek dukungan keluarga yaitu: dukungan emosional, dukungan informasi, dukungan instrumental, dukungan penghargaan.

\section{Hipotesis Minor}

Ada hubungan positif antara kecerdasan emosi dengan penerimaan diri orang tua anak berkebutuhan khusus (ABK) artinya semakin tinggi kecerdasan emosi maka semakin tinggi penerimaan diri orang tua anak berkebutuhan khusus ( $A B K)$, dan sebaliknya semakin rendah kecerdasan emosi maka semakin rendah penerimaan diri orang tua anak berkebutuhan khusus (ABK).

Ada hubungan positif antara dukungan keluarga dengan penerimaan diri orang tua anak berkebutuhan khusus (ABK) artinya semakin tinggi dukungan keluarga maka semakin tinggi penerimaan diri orang tua anak berkebutuhan khusus (ABK), sebaliknya semakin rendah dukungan keluarga maka semakin rendah penerimaan diri orang tua anak berkebutuhan khusus (ABK)

\section{METODE PENELITIAN}

Teknik pengambilan sampel yang digunakan dalam penelitian ini adalah incidental sampling yaitu teknik penentuan sampel berdasarkan kebetulan saja, anggota populasi yang ditemui bersedia menjadi responden untuk dijadikan sampel (Siregar, 2013). Sugiyono (2015) menyatakan bahwa incidental sampling adalah teknik penentuan sampel berdasarkan kebetulan, yaitu siapa saja yang secara kebetulan bertemu dengan peneliti dapat digunakan 
sebagai sampel, bila dipandang orang yang kebetulan ditemui tersebut cocok sebagai narasumber.

Penentuan sampel yang dipakai dalam penelitian adalah siapa saja orang tua yang mempunyai anak kebutuhan khusus secara kebetulan bertemu dengan peneliti yang masuk dalam populasi. Sedangkan populasi dalam penelitian ini adalah orang tua yang mempunyai anak kebutuhan khusus (ABK) di sekolah SLB Cendono Kudus, SDLB Purwosari Kudus, Pondok Pesantren Autis Al Achsanniyah Pedawang, dan daerah sekitaran Mlati Norowito.

Jenis skala yang digunakan dalam penelitian ini adalah skala secara langsung, yaitu skala yang diberikan kepada subjek secara langsung yang akan dimintai pendapat, keyakinan ataupun diminta untuk menceritakan keadaan dirinya sendiri (Hadi, 2000). Skala yang digunakan dalam penelitian ini ada tiga macam, yaitu skala yang menggungkapkan: Skala penerimaan diri menurut Jersild, Brook \& Brook (1978), Skala kecerdasan emosional menurut Goleman (2015), dan skala dukungan keluarga menurut Friedman (1998). Azwar \& Soegiyono (Siregar, 2015) mengatakan bahwa untuk menentukan valid atau tidak dapat diukur dengan koefisien korelasi product moment melebihi 0,3. Cara yang digunakan dalam menghitung reliabilitas penelitian ini adalah dengan menggunakan teknik reliabilitas koefisien Alpha yang digunakan oleh Cronbach dengan menggunakan alat bantu komputer dan program Statistical Packages for Social Sciences (SPSS) 16.0 for window. Menurut Azwar (2003) menyatakan bahwa koefisien reliabilitas berada dalam rentang 0 sampai dengan 1 , artinya ketika mendekati nilai 1 maka semakin tinggi reliabilitas itu tetapi ketika menjauhi nilai 1 maka akan semakin rendah reliabilitas itu.

Metode statistika yang dipakai dalam penelitian ini adalah teknik analisis Regresi Dua Prediktor, dipakai untuk mencari ada tidaknya hubungan antara penerimaan diri sebagai variabel tergantung, serta kecerdasan emosi dan dukungan keluarga sebagai variabel bebas. Untuk menguji hubungan antara penerimaan diri dengan kecerdasan emosi serta hubungan antara penerimaan diri dengan dukungan keluarga menggunakan teknik analisis korelasi product moment dengan menggunakan program Statistical Packages for Social Sciences (SPSS) 16.0 for window.

\section{HASIL DAN PEMBAHASAN}

Penyebaran skala dilakukan pada 47 sampel orang tua yang memiliki anak berkebutuhan khusus yang kebetulan bertemu tetapi yang terpakai hanya 40 sampel orang tua yang memiliki anak berkebutuhan khusus.

Hasil uji hipotesis minor pertama menunjukkan adanya koefisien korelasi variabel $r_{\text {_ }}(\mathrm{x} 1, \mathrm{y})$ sebesar 0,745 dengan besaran $p$ sebesar $0,000 \quad(\mathrm{p}<0,01)$. Hasil tersebut menunjukkan bahwa ada hubungan positif yang sangat signifikan antara kecerdasan emosional dengan penerimaan diri artinya semakin tinggi kecerdasan emosional maka 
semakin tinggi penerimaan diri sebaliknya semakin rendah kecerdasan emosional maka semakin rendah penerimaan diri.

Hipotesis minor pertama yang diajukan dalam penelitian ini adalah ada hubungan positif yang sangat signifikan antara kecerdasan emosional dengan penerimaan diri artinya semakin tinggi kecerdasan emosional maka semakin tinggi penerimaan diri sebaliknya semakin rendah kecerdasan emosional maka semakin rendah penerimaan diri. Dengan demikian, hipotesis yang diajukan dalam penelitian ini diterima.

Sehingga dapat dikatakan bahwa dengan kecerdasan emosi, individu akan memiliki penerimaan diri dan ketika ada perasaan stress seorang akan mampu menghadapinya karena memiliki kecerdasan emosi yang baik, dimana menurut Harningsih (2008) menjelaskan bahwa individu yang mampu menerima keadaan diri dan mampu menyesuaikan diri adalah individu yang mampu mengendalikan emosi dan mempunyai motivasi dalam dirinya sehingga mengusahakan tindakan nyata untuk menghadapi dan melewati masa tersebut karena menyadari bahwa yang dilakukan akan bermanfaat bagi dirinya sendiri dikemudian hari.

Segal (Harningsih, 2008) mengatakan bahwa orang yang tidak dapat menerima emosi berarti tidak dapat menerima dirinya sendiri karena sering menyalahkan orang lain atas kemarahan yang dirasakannya dan meyakinkan diri bahwa kesedihan dan kecemasan itu memalukan, apabila tidak sepenuhnya menerima emosi, individu akan kehilangan kebijaksanaan dalam membuat keputusan yang tepat untuk bertindak. Individu dapat menerima dirinya dengan baik apabila dapat menerima emosi yang ada dalam dirinya dengan baik maka individu tersebut membutuhkan kecerdasan emosi yang baik untuk menerima keadaannya.

Hurlock (2013) menjelaskan bahwa tidak adanya tekanan emosi membuat seseorang dapat melakukan yang terbaik dan dapat berpandangan keluar dan tidak memiliki pandangan hanya ke dalam diri saja. Tanpa tekanan emosi juga dapat membuat seseorang santai dan bahagia. Kondisi-kondisi ini memberikan sumbangan positif bagi penilaian terhadap lingkungan sosial yang menjadi dasar terhadap penilaian diri sendiri dan terhadap penerimaan diri. Disamping itu, Salovey dan Mayer (Goleman, 2000) berpendapat bahwa orang yang cerdas secara emosi lebih mampu mengenali perasaan dan sadar akan suasana hati maupun pikiran tentang suasana hatinya sendiri. Dengan demikian, individu tidak mudah larut dan dikuasai emosinya. Sehingga sangatlah penting individu memiliki kecerdasan emosi, karena dengan kecerdasan emosi, individu dapat menerima dirinya sendiri.

Didukung dengan hasil penelitian yang dilakukan oleh Eliyanto dan Hendriani (2013) berjudul Hubungan Kecerdasan Emosi dengan Penerimaan Ibu terhadap Anak Kandung yang Mengalami Cerebral Palsy, dimana hasil menunjukkan adanya hubungan antara kecerdasan emosi dengan penerimaan diri ibu anak kandung yang mengalami cerebral palsy. Semakin tinggi kecerdasan emosi ibu anak kandung yang mengalami cerebral palsy akan semakin 
tinggi penerimaan diri anak kandung yang mengalami cerebral palsy, sebaliknya semakin rendah kecerdasan emosi anak kandung yang mengalami cerebral palsy maka semakin rendah penerimaan diri ibu anak kandung yang mengalami cerebral palsy. Wardani (2012), melakukan penelitian serupa dimana hasil penelitian menunjukkan ada hubungan antara kecerdasan emosional dengan penerimaan teman sebaya.

Hasil uji hipotesis minor kedua menunjukkan adanya koefisien korelasi variabel dukungan keluarga dengan penerimaan diri $r_{-}(x 2, y)$ sebesar 0,461 dengan besaran $p$ sebesar 0,001 $(p<0,01)$ maka ada hubungan positif yang sangat signifikan antara dukungan keluarga dengan penerimaan diri artinya semakin tinggi dukungan keluarga maka semakin tinggi penerimaan diri sebaliknya semakin rendah dukungan keluarga maka semakin rendah penerimaan diri.

Hipotesis minor yang diajukan dalam penelitian ini adalah ada hubungan positif yang sangat signifikan antara dukungan keluarga dengan penerimaan diri artinya semakin tinggi dukungan keluarga maka semakin tinggi penerimaan diri sebaliknya semakin rendah dukungan keluarga maka semakin rendah penerimaan diri.

Penerimaan diri dipengaruhi oleh dukungan sosial dimana dukungan sosial itu sendiri bisa berasal dari keluarga. Hal tersebut dijelaskan oleh Hurlock (2013) menyatakan bahwa sikap-sikap anggota keluarga yang menyenangkan dan tidak adanya prasangka buruk lingkungan terhadap seorang ibu yang mengalami kondisi sulit untuk menerima dirinya sendiri, merupakan salah satu faktor seseorang dapat melakukan penerimaan diri.

Kemudian Sarasvati (2004), penerimaan orang tua terhadap anak dipengaruhi oleh ada atau tidaknya dukungan sosial dari orang-orang disekitar karena manusia takkan lepas dari orang lain. Menurut Sarafino (1990), dukungan sosial sendiri dapat berasal dari berbagai sumber yaitu pasangan hidup, keluarga, pacar, teman, rekan kerja, dan organisasi komunitas. Dukungan sosial yang bersumber dari keluarga disebut dukungan sosial keluarga.

Friedman (1998) menjelaskan bahwa dukungan keluarga adalah sikap, tindakan serta penerimaan keluarga terhadap anggotanya. Anggota keluarga dipandang sebagai bagian yang tidak terpusahkan dalam lingkungan keluarga. Anggota keluarga memandang bahwa orang yang bersifat mendukung selalu siap memberikan pertolongan dan bantuan ketika diperlukan.

Penelitian yang dilakukan oleh Utami (2013) berjudul Hubungan Antara Dukungan Sosial Keluarga dengan Penerimaan Diri Individu yang Mengalami Asma, hasil penelitian menunjukkan nilai $r$ sebesar 0,687 dengan besaran $p$ sebesar 0,000 . Berdasarkan hasil tersebut menunjukkan bahwa terdapat hubungan yang positif antara dukungan sosial keluarga dengan penerimaan diri individu yang mengalami asma, artinya dalam penelitian ini semakin tinggi dukungan keluarga maka semakin tinggi pula penerimaan diri individu yang 
mengalami asma, sebaliknya semakin rendah dukungan keluarga maka semakin rendah pula penerimaan diri individu yang mengalami asma.

Adapun pengaruh antara variabel kecerdasan emosi, dukungan keluarga dengan penerimaan diri koefisiensi determinasi $\mathrm{R}$ Square sebesar 0,587 menjelaskan sumbangan efektif kecerdasan emosi dan dukungan keluarga terhadap penerimaan diri sebesar $58,7 \%$. sehingga terdapat $41,3 \%$ yang dipengaruhi oleh faktor lain yang mempengaruhi penerimaan diri. Sumbangan efektif yang diberikan variabel kecerdasan emosi terhadap penerimaan diri sebesar $55,5 \%$, sedangkan untuk variabel dukungan keluarga terhadap penerimaan diri mempunyai sumbangan efektif sebesar $21,3 \%$.

Faktor yang mempengaruhi variabel penerimaan dari Hurlock (2013) yaitu pemahaman diri, harapan yang realistis, tidak adanya hambatan-hambatan dari lingkungan, tingkah laku sosial yang mendukung (dukungan sosial), tidak adanya tekanan emosi yang berat (kecerdasan emosi), pengaruh keberhasilan yang dialami, baik secara kualitatif maupun kuantitatif, identifikasi dengan orang yang mempunyai penyesuaian diri yang baik, cara seseorang melihat diri sendiri (konsep diri), pendidikan yang baik pada masa kanak-kanak.

\section{KESIMPULAN}

Berdasarkan hasil analisis data yang telah dilakukan didapatkan hasil penelitian bahwa ada hubungan positif yang sangat signifikan antara kecerdasan emosional dengan penerimaan diri dan ada hubungan positif yang sangat signifikan antara dukungan keluarga dengan penerimaan diri. Sumbangan efektif kecerdasan emosi dan dukungan keluarga terhadap penerimaan diri sebesar $58,7 \%$. Sedangkan sumbangan efektif yang diberikan variabel kecerdasan emosi terhadap penerimaan diri sebesar $55,5 \%$, untuk variabel dukungan keluarga terhadap penerimaan diri mempunyai sumbangan efektif sebesar $21,3 \%$.

\section{SARAN}

Bagi Orang Tua

Bagi orang tua yang memiliki penerimaan diri rendah yaitu:

Meningkatkan kecerdasan emosi. Cara meningkatkan kecerdasan emosi adalah dengan mengenali emosi, mengelola emosi, memotivasi diri sendiri, mengenali emosi orang lain, serta membina hubungan dengan orang lain

Meningkatkan dukungan keluarga. Cara yaitu dengan meningkatkan dukungan emosional, dukungan informasi, dukungan instrumental, serta dukungan penghargaan.

\section{Bagi Peneliti}

Disarankan agar dapat menyempurnakan hasil penelitian ini dari sisi item atau melibatkan variabel lain. Selain itu, penelitian yang melibatkan orang tua dari anak 
berkebutuhan khusus biasanya mengalami kesulitan dalam mengumpulkan subjek penelitian, sehingga diharapkan peneliti selanjutnya mampu melakukan pendekatan terlebih dahulu kepada subjek agar didapatkan hasil penelitian yang lebih memuaskan. 


\section{DAFTAR PUSTAKA}

Ahmadi, A. (2007). Psikologi Sosial. Cetakan 3 (Edisi Revisi). Jakarta: Rineka Cipta.

Ananwong, P, D., Tuicomepee, A., dan Kotrajaras, S . (2013). Self-Acceptance of Sexual Orientation In Gay Men: A Consensual Qualitative Research. International J ournal. Diakses tanggal 23 Januari 2017 dari http://iafor.org/archives/offprints/acp2013offprints/acp20130272.pdf.

Aydin, A. Yamac, A. (2014). The Relations between The Acceptance and Child-Rearing Attitudes of Parents of Children with Mental Disabilitie. Eurasian journal of educational research, issue 54. Diakses tanggal 22 November 2016 dari http://files.eric.ed.gov/fulltext/ej1057330.pdf

Azwar, S. (2000). Tes Prestasi Fungsi dan Pengembangan Pengukuran Prestasi Belajar. Yogyakarta: Pustaka Pelajar

(2003). Penyusunan Skala Psikologi. Yogyakarta: Pustaka Pelajar Offset.

Baron, R, A. Byrne, D. (2005). Psikologi Sosial. Edisi Kesepuluh. Jilid 2. Jakarta: Erlangga

Batool, B, F. (2013). Emotional Intelligence and Effective Leadership. J ournal of Business Studies Quarterly. Vol 4, No 3. Diakses tanggal 22 November 2016 dari http://tarjomeh20.com/wp-content/uploads/2015/05/emotional-intelligence-and s6d5a2fdadd0.pdf.

Brooks, J. (2011). The Process of P arenting. Edisi Kedelapan. Yogyakarta: Pustaka Pelajar.

Davies, M. F. (2007). Irrational Beliefs and Unconditional Self-Acceptance. Ii. Experimental Evidence for A Causal Link between Two Key Features of Rebt. J ournal of RationalEmotive \& Cognitive-Behavior Therapy. Diakses tanggal 13 Juni 2016 dari http://research.gold.ac.uk/2/1/jrecbt2 online.pdf

Eliyanto, H. Hendriani, W. (2013). Hubungan Kecerdasan Emosi dengan Penerimaan Ibu Terhadap Anak Kandung Yang Mengalami Cerebral Palsy. J urnal. Diakses tanggal 13 Juni 2016 dari http://journal.unair.ac.id/filerpdf/jpppb14962ae24full.pdf

Faradina, N. (2016). Penerimaan Diri pada Orang Tua yang memiliki Anak Berkebutuhan Khusus. eJournal Psikologi. Vol 4 No 4. Diakses tanggal 25 Januari 2017 dari http://ejournal.psikologi.fisipunmul.ac.id/site/wpcontent/uploads/2016/03/ejournal_nov ira\%20faradina\%20(ONLINE)\%20(03-17-16-07-16-01).pdf

Fareo, D. O. (2015). Counselling Intervention and Support Programmes for Families of Children with Special Educational Needs. J ournal of Education and Practice. Vol. 6, $\begin{array}{lllll}\text { No.10. Diakses tanggal } 23 & \text { Januari }\end{array}$ http://files.eric.ed.gov/fulltext/ej1081793.pdf.

Friedman, M. (1998). Keperawatan Keluarga Teori dan Praktik. Edisi 3. Jakarta: Egc. 
Feldman, P. O. (2013). Human Development Perkembangan Manusia. Edisi Kesepuluh. Jakarta: Salemba Humanika.

Geniofam. (2010). Mengasuh dan Mensukseskan Anak Berkebutuhan Khusus. Yogjakarta: Garailmu.

Goleman, D. (2000). Kecerdasan Emosi untuk Mencapai Puncak Prestasi. Jakarta: Pt. Gramedia Pustaka Utama.

. (2015). Emotional Intelligence. Jakarta: PT. Gramedia Pustaka Utama.

Hadi, S. (2000). Statistik. Jilid 2. Yogyakarta: Andi Yogyakarta.

Harningsih, T. (2008). Kecerdasan Emosi dan Penerimaan Diri pada Korban Narkoba di Lembaga Pemasyarakatan. Skripsi. Dikases tanggal 22 Januari 2017 dari http://eprints.ums.ac.id/855/1/f100040160.pdf

Hurlock, E. B. (2013). Psikologi Perkembangan: Suatu Pendekatan Sepanjang Rentang Kehidupan. Edisi Kelima. Jakarta: Erlangga.

Jersild, A. T. Brook, J. S. Brook, D. W. (1978). The Psychology Of Adolescence. Third Edition. New York: Macmillan Publishing Co., Inc.

Kompas.(2015). Diakses tanggal $23 \quad$ Januari 2017 dari http://health.kompas.com/read/2015/12/12/091000223/anak.berkebutuhan.khusus.bu tuh.penanganan.bukan.air.mata?page=all

Lestari, S. (2013). Psikologi Keluarga Penanaman Nilai dan Penanganan Konflik dalam Keluarga. Jakarta: Kencana.

Levianti, M. (2013). Penerimaan Diri lbu Yang Memiliki Anak Tunanetra. J urnal Psikologi. Vol 11 No 1. Diakses tanggal 30 Januari 2017 dari http://download.portalgaruda.org/article.php?article=178184\&val=4564\&title=Penerim aan\%20Diri\%20lbu\%20Yang\%20Memiliki\%20Anak\%20Tunanetra.

Marni, A. Yuniawati, R. (2015). Hubungan antara Dukungan Sosial dengan Penerimaan Diri pada Lansia di Panti Wredha Budhi Dharma Yogyakarta. J urnal Fakultas Psikologi. Vol. 3 No 1 . Dikases tanggal 20 Januari 2017 dari http\%3a\%2f\%2fjournal.uad.ac.id\%2findex.php\%2fempathy\%2farticle\%2fdownload\% 2f3008\%2f1747\&usg=afqjcnfomdzoxxf4scmqzh2sk-mcuo0r-w

Meilinda, E. (2013). Hubungan antara Penerimaan Diri dan Konformitas terhadap Intensi Merokok pada Remaja di SMK Istiqomah Muhammadiyah 4 Samarinda. Ejournal Psikologi. Vol. 1 No.1. Diakses tanggal 13 Juni 2016 dari http://ejournal.psikologi.fisipunmul.ac.id/site/wpcontent/uploads/2013/03/jurnal\%(0311-13-05-54-50).pdf.

Mirza, A. M. (2016). Hubungan antara Kecerdasan E mosional dengan Penerimaan Diri Santri Pondok Pesantren AI-Islam Genengan Mojokerto. Undergraduate thesis. Universitas 
Islam Negeri Maulana Malik Ibrahim. Diakses tanggal 30 Januari 2017 dari http://etheses.uin-malang.ac.id/4045/

Nazir. (2009). Metode Penelitian. Bandung: Ghalia Indonesia.

Pancawati, R . (2003). Penerimaan Diri dan Dukungan Orangtua terhadap Anak Autis.

Ejournal Psikologi. Vol 1. Diakses tanggal 13 Juni 2016 dari http://ejournal.psikologi.fisipunmul.ac.id/site/wpcontent/uploads/2013/04/jurnal 20ririn\%20pancawati\%20\%2804-04-13-04-35-13\%29.pdf

Prayitna, E. Lestari, S. Supriyono, Y. (2014). Hubungan antara Dukungan Sosial dengan Penerimaan Orang Tua Anak Autisme. J urnal. Diakses tanggal 13 Juni 2016 dari http://psikologi.ub.ac.id/wp-content/uploads/2014/11/jurnal-emylia-prayitna105120306111001 .pdf.

Purwanto. (2011). Statistika untuk Penelitian. Yogyakarta: Pustaka Pelajar.

Puspita, D. (2004). Peran Keluarga pada Penanganan Individu Autistic Spectrum Disorder. Diakses tanggal 13 Juni 2016 dari http://puterakembara.org/rm/peran_ortu.htm

Rachmayanti, S. Zulkaida, A. (2007). Penerimaan Diri Orangtua terhadap Anak Autisme dan Peranannya dalam Terapi Autisme. Jurnal psikologi. Vol 1. Diakses tanggal 14 September 2016 dari http://dosen.narotama.ac.id/wpcontent/uploads/2012/03/penerimaan-diri-orangtua-terhadap-anak-autisme-danperanannya-dalam-terapi-autisme.pdf

Rizkiana, U. (2009). Penerimaan Diri pada Remaja Penderita Leukemia. J urnal psikologi. Vol. 2 No. 2. Diakses tanggal 13 Juni 2016 dari http://ejournal.gunadarma.ac.id/files/journals/7/articles/265/public/265-788-1-pb.pdf

Safaria, T, Saputra, N. E. (2012). Manajemen Emosi. Jakarta: Bumi Aksara.

Safree, A. Yasin. Dzulkifli, M. A.(2010). The Relationship between Social Support and Psychological Problems Among Students. International Journal of Business and Social Science. Vol. 1 No. 3. Diakses tanggal 20 Desember 2016

dari http://ijbssnet.com/journals/vol. 1 no. 3 december 2010/11.pdf

Santrock, J, W. (2007). Perkembangan Anak. Edisi 11. Jilid 1. Jakarta: Erlangga.

Sarafino, E, P. (1990). Health Psychology: Biopychosocial Interaction. United States Of America: John Wiley \& Sons, Inc.

Sarasvati. (2004). Meniti Pelangi: Perjalanan Seorang Ibu yang Tak Kenal Menyerah dalam Membimbing Putranya Keluar dari Belenggu ADHD dan Autisme. Jakarta: PT. Elex Media Kompatindo.

Sarwono, S, W. (2005). Psikologi Sosial: Berbagi Kelompok dan Berbagi Terapan. Jakarta: Balai Pustaka.

Schultz, D. (1991). Psikologi Pertumbuhan Model-Model Kepribadian Sehat. Yogyakarta: Kanisius. 
Sears, D, O. Freedman, J, L. Peplau, L, A. (1994). Psikologi Sosial. Edisi 5. Jilid 1. Jakarta: Erlangga.

Siregar, S. (2015). Metode Penelitian Kuantitatif. Jakarta: Prenadamedia Group.

Sobur, A. (2003). Psikologi Umum dalam Lintasan Sejarah. Bandung: Pustaka Setia Bandung. Somantri, S. (2007). Psikologi Anak Luar Biasa. Bandung: Refika Aditama.

Suara. (2014). Diakses tanggal 23 Januari 2017 dari http://www.suara.com/health/2014/12/10/123758/anak-berkebutuhan-khusus-banyakdisembunyikan-keluarganya.

Sugiarti, L. (2008). Gambaran Penerimaan Diri pada Wanita Involuntary Childless. Skripsi. Jurusan Psikologi Fakultas Psikologi Universitas Indonesia. Diakses tanggal 23 Februari 2017 dari http://journal.uinsgd.ac.id.

Sugiyono. (2015). Statistika untuk Penelitian. Bandung: Alfabeta.

Taylor, S. E, Peplau, L. A., Sears, D.O. (2009). Psikologi Sosial. Edisi Kedua Belas. Jakarta: Kencana

Twistiandayani, R. Ratnahandika, S. (2015). Hubungan Dukungan Keluarga dengan Penerimaan Diri lbu yang mempunyai Anak Autis (Correlation Family Support with Self Acceptance of Mother Who Have Children with Autism). J urnal IImu Keperawatan Fakultas Ilmu Kesehatan Universitas Gresik. Vol 6. Diakses tanggal 14 September 2016 dari http://journal.unigres.ac.id/index.php/jnc/view/45/44

Utami, N, M, S, N. (2013). Hubungan antara Dukungan Sosial Keluarga dengan Penerimaan Diri Individu Yang Mengalami Asma. J urnal Psikologi U dayana. Vol. 1. No. 1. Diakses tanggal 23 Januari 2017 dari http://e-jurnal.com/2013/12/hubungan-antara-dukungansosial.

Wardani, F, E. (2012). Hubungan antara Kecerdasan Emosional dengan Penerimaan Teman Sebaya pada Siswa Akselerasi SMA Negeri 8 Pekanbaru. S kripsi. Diakses tanggal 23 Januari 2017 dari http://repository.uin-suska.ac.id/3913/1/2013 201301psi.pdf

Wardhani, M. K. Rahayu, M. S. Rosiana, D. (2012). Hubungan antara Personal Adjustmen dengan Penerimaan Terhadap Anak Berkebutuhan Khusus Pada Ibu Yang Memiliki Anak Berkebutuhan Khusus di RSUD X. Prosiding Fakultas Psikologi Universitas Islam Bandung. Diakses tanggal 3 Februari 2017 dari http://prosiding.lppm.unisba.ac.id/indec.php/sosial/article/view/230/pdf

Wibawa, A. G. (2014). Hubungan Dukungan Sosial Keluarga dengan Penerimaan Diri lbu Anak Autis Di SDLB-B dan Autis TPA (Taman Pendidikan dan Asuhan) Kecamatan Patrang Kabupaten Jember. Skripsi Keperawatan. Diakses tanggal 14 September 2016

dari http://repository.unej.ac.id/bitstream/handle/123456789/57541/alvidzius\%20gusti\%20 wibawa\%20-\%20082310101020_1.pdf?sequence=1 
Wijayanti, D. (2015). Subjective Well-Being dan Penerimaan Diri lbu Yang Memiliki Anak Down Syndrome. Ejournal Psikologi. Diakses tanggal 14 September 2016 dari http://ejournal.psikologi.fisipunmul.ac.id/site/wpcontent/uploads/2015/12/ejounal\%20dian\%2 Owijayanti\%20(12-08-15-06-26-24).pdf

Zulqaidah. (2016). Diakses tanggal 23 Januari 2017 dari http://www.republika.co.id/berita/koran/leasure/14/12/16/ngny4a4-parenting-hakanak-difabel 